\title{
ERASMO DE ROTTERDAM NO DEBATE ENTRE O HUMANISMO, A ES- COLÁSTICA E A REFORMA
}

\author{
Sidnei Francisco do Nascimento ${ }^{1}$ \\ Universidade Federal do Maranhão (UFMA) \\ (iD) https://orcid.org/0000-0001-9218-1184
}

\section{RESUMO:}

O humanista fez parte de um debate, em que, preferia a moderação, pois pretendia não colocar mais "óleo na fogueira". No entanto, o que aconteceu foi justamente o contrário: ele acirrava ainda mais os ânimos e se colocava entre dois partidos opostos, a saber, a ortodoxia de um lado e, do outro, Lutero e os luteranos. Curiosa situação! Erasmo era a favor e contra a ortodoxia e os dissidentes.

PALAVRAS-CHAVE: Erasmo de Rotterdam; Orígenes; Lutero; Humanismo; Escolástica; Exegese; Alegoria.

\section{ERASMUS OF ROTTERDAM IN THE DEBATE BETWEEN HUMANISM, SCHOLASTICISM AND REFORMATION}

\begin{abstract}
:
The humanist took part in a debate in which he opted for moderation, since he did not intend to "add fuel to the flames". However, what happened was exactly the opposite: he stirred up animosity by placing himself between two opposite poles, namely, orthodoxy in one corner, and Luther and Lutherans in the other corner. Peculiar situation! Erasmus was, at the same time, in favor and against orthodoxy and the dissidents.
\end{abstract}

KEYWORDS: Erasmus of Rotterdam; Origen; Luther; Humanism; Scholasticism; Exegesis; Allegory.

\footnotetext{
${ }^{1}$ Doutor em Filosofia pela Pontifícia Universidade Católica de São Paulo (PUCSP), São Paulo - Brasil. Professor de Ética e Filosofia Política da Universidade Federal do Maranhão (UFMA), Brasil. E-mail: sidneifn@bol.com.br
}

NASCIMENTO, Sidnei Francisco do. Erasmo de Rotterdam no debate entre o humanismo, a escolástica e a reforma. Griot: Revista de Filosofia, Amargosa, Bahia, v.16, n.2, p.56-66, dezembro/2017. 
O debate a respeito da relação entre exegese e alegoria envolvia, a teologia escolástica e o humanismo cristão. No início, a discussão, que estava confinada dentro do ambiente universitário, se propagava rapidamente com o advento das tipografias e consequentemente com a edição e a publicação de livros. O mercado editorial estava aquecido, e os bons tradutores, por sua vez, preocupadíssimos em desenvolver e encontrar as melhores traduções em suas respectivas fontes. Para exemplificar a discussão entre os editores e os tradutores ressalto que Erasmo de Rotterdam não duvidava de que a Epístola aos Romanos tivesse sido traduzida por Jerônimo, mas rejeitava aqueles impudentes manipuladores de prefácio que acreditavam que teria sido traduzida por Rufino de Aquileia. Erasmo era da opinião que Rufino só se interessava pelas obras dos grandes autores com o intuito de contaminá-las, o que significava reduzir a obra praticamente pela metade. Estaria a caminho uma revolução intelectual e sociocultural que dividiria a sociedade cristã do século XVI?

Hactenus impossuit mihi titulus et peroratio Commentariorum Origeneis in Epistolam ad Romanos, ut crederem eos ab Hieronymo versos, tametsi de phrasi dubitabam nonnihil, quae tamen hic mihi visa est purior quam in caeteris versionibus est Ruffini. Magis autem offenebat admixta multa, quae partim a graeco scriptore romani sermonis ignaro dici non poterant, partim ex diâmetro pugnant cum Origenis dogmatibus. Hieronymus autem in vertendo religiosor est quam Ruffinus, qui non solum permittit sibi de suo sententias aliquot intertexere, verum etiam totos libros praetermittit, et pro his suos supponit. Unde propemodum pedibus eo in sententim eorum, qui putant hanc versionem esse Ruffini. (LB. 1706, Livro VI). ${ }^{2}$

A escolástica ao final da Idade Média se tornava, aos olhos dos humanistas, uma instituição monolítica que visava exclusivamente o monopólio da educação. A ratio docendi, quero dizer, o método de ensino desenvolvido dentro das escolas urbanas do século XII e a partir do século XIII nas universidades mantinha o controle, a organização e os modos de conhecimento que permaneciam restritos à ortodoxia e à teologia oficial. A proeminência da filosofia de Aristóteles no século XIII fora favorecida pelos tradutores latinos da literatura greco-árabe. A ratio docendi privilegiava a auctoritas, a lectio e a disputatio para estudar as obras de Aristóteles, as sumas de teologia, a Bíblia e o Livro das sentenças de Pedro Lombardo. A aplicação desse método constituía o universo intelectual que seria conhecido como a Escolástica medieval, a qual, por sua vez ganharia uma reputação desfavorável que se ligaria ao verbalismo

\footnotetext{
2 “Até o presente, concedo o título e a declamação dos comentários de Orígenes à Epístola aos Romanos aos versos de Jerônimo, ainda que nada duvidasse do estilo, que me parece que está tão purificado, como raramente estão os versos de Rufino. Porém, esse errava na mistura de muitas opiniões, quando, por exemplo afirmava, por um lado, que não se podia ignorar os escritos gregos nem os sermões romanos, mas, por outro lado, ao mesmo tempo, combatia contra as dogmáticas de Orígenes. Rufino é tão religioso quanto Jerônimo, que não só se permitia preparar e tecer algumas sentenças, como também negligenciava todos os verdadeiros livros que em relação aos quais, especulava. Donde aquela Epístola aos Romanos que os manipuladores de prefácio julgavam ser a versão de Rufino." (Tradução nossa.)
}

NASCIMENTO, Sidnei Francisco do. Erasmo de Rotterdam no debate entre o humanismo, a escolástica e a reforma. Griot: Revista de Filosofia, Amargosa, Bahia, v.16, n.2, p.56-66, dezembro/2017. 
vazio porque, na opinião dos homens de letras do século XVI, se perdera em discussões estéreis. A influência da filosofia especulativa de Aristóteles se manifestava no desenvolvimento e aplicação do método. Numa cristandade dominada pelo saber universitário, a teologia se tornara especulativa e a mãe normativa do saber. Erasmo se perguntava como seria tratar de temas como o pecado, a penitência, a graça, a natureza, a justificação, o livre-arbítrio recorrendo à lógica de Aristóteles e não à caridade. $O$ ambiente do futuro teólogo exegeta deverá se constituir mais em affectus do que em argúcias.

Qual Aristóteles, não teria o ar estúpido, ignorante e frívolo, comparado a esses homens que tomaram a sabedoria celeste na sua própria fonte, sabedoria que faz aparecer toda espécie de sabedoria humana como uma pura estupidez? Que isso seja dito sem querer ofender aqueles que estimam que seja um crime e sacrilégio diminuir em qualquer ponto a autoridade de Aristóteles. Eu reconheço que ele foi um homem de um saber excepcional, mas qual luz, se radiosa fosse ela, não se obscureceria em sua comparação com o Cristo? (ÉRASME. 1998, p.10)

Qual a maneira mais adequada para se estudar, compreender e passar adiante os ensinamentos bíblicos? Para responder a questão, será necessária primeiramente a escolha de um bom método de ensino adequado aos novos tempos, depois se deveria escolher bons autores, de preferência aqueles que fizeram parte da literatura patrística. A seguir se deveria escolher um excelente tradutor e, por último, seria necessário um pius theologus que gostasse de ensinar as bonae litterae e que não estivesse comprometido com a faculdade de teologia de Paris e nem com os interesses da Reforma. Os teólogos aristotélicos, ao contrário, embora reconhecidos com saberes inigualáveis, aos olhos de Erasmo perverteram a doutrina cristã fazendo desta uma busca puramente intelectual.

quid Alberto Magno, quid Alexandro, quid Thomae, quid Aegidio, quid Ricardo, quid Occam alii velint tribuere, per me sane cuique liberum erit, nolim enim cujusquam imminuere gloriam, aut cum inveteratis jam hominum studiis dimicare. Sint illa quantumvis erudita, quantumvis subtilia, quantumvis si velint seraphica, haec tamen certissima fateantur oportet. Paulus dijudiari vult spiritus prophetarum, num ex deo sint. (ÉRASME, 1990, p.86) $)^{3}$

A opção seria muito simples se não estivesse envolvida numa trama de interesses e de poder, de lutas de influência, de clivagens sócioculturais, de discursos circunstanciados. Esses são fenômenos possíveis de se analisar porque aparecem como

3 A citação é uma alusão irônica que Erasmo faz a Duns Escoto como o "doutor subtil" e a São Boaventura como o “doutor seráfico": “O que Alberto Magno, Alexandro, Tomás, Aegídio, Ricardo, Occam e outros querem, para mim estará inteiramente permitido, porque não quero diminuir a glória de quem quer que seja, ou lutar com paixão contra os homens antigos, tão grandes eruditos, com tantas subtilidades, que se concebem tão grandes 'seráficos'. Contudo é necessário que esses sejam reconhecidos como muito honestos. Paulo pretende que seja observado que os espíritos dos profetas sejam de Deus." (Tradução nossa.)

NASCIMENTO, Sidnei Francisco do. Erasmo de Rotterdam no debate entre o humanismo, a escolástica e a reforma. Griot: Revista de Filosofia, Amargosa, Bahia, v.16, n.2, p.56-66, dezembro/2017. 
resultados das relações entre saber e poder dentro da universidade, em que suas estruturas medievais são colocadas em xeque por novas correntes de pensamentos. Nesse momento a exegese de Erasmo demonstrava uma espécie de terrorismo intelectual. ${ }^{4}$ Quando nos referimos à ortodoxia, não seria toda literatura dos primeiros padres a mais indicada para ser utilizada nos meios acadêmicos. Orígenes, por exemplo, era um autor proibido, e a justificativa para a proibição de suas obras girava em torno de suas alegorias contrárias aos métodos tradicionais desenvolvidos e ratificados pelos teólogos da Sorbonne. Os que pertenciam à tradição criticavam os humanistas que se opunham à ratio studiorum da faculdade de teologia e os aproximavam deliberadamente às causas da Reforma. Erasmo era acusado de romper com a ortodoxia a favor de Lutero quando assimilava a teologia de Orígenes. A esse respeito escreveu o representante da faculdade de teologia Noël Béda em 1526:

Quo eiusmodi aegritudini medicos, id est sacrarum literarum professores, isti humanistae theologizantes cum Luthero (quem in multis docuisse videntur quam quam ab eo didicisse: nimirum quo priores multa ediderant quae ipse dum scriberet vidisse potuit) velut suae artis plane imperitos aspernarentur. 5 (GODIN, A. apud BÉDA, N., 1982, p.425)

No que se refere aos interesses da Reforma, a escolha era ainda mais seletiva. Sabe-se que Lutero deblaterava contra Jerônimo, Orígenes e os padres da Igreja, e mesmo com a prerrogativa (que ele se atribuía) de agostiniano, contrário ao doutor de Hipona, amplificava a importância do mito do pecado original e acreditava que, por esse motivo, o pecado tivesse obscurecido completamente a razão, o que inviabilizaria o conceito de livre-arbítrio e de justificação pelas obras. In Pharaonem, quanquam fuerat derelictus, manere tamen arbitrium liberum, Augustinus plane confitetur ${ }^{6}$. (GODIN, A. apud J.FISHER, J. 1527, p. 713)

Dentro desse contexto de discórdias e para acentuá-lo ainda mais reapareciam as obras de Orígenes, que permaneciam como uma espécie de vida em latência, preservadas nas bibliotecas medievais, mas, quando ressurgiam, coincidiam com os grandes momentos de crises e de crescimento que marcaram o Renascimento dos séculos IX, XII e XVI. Marcilio Ficino e a academia platônica de Florença, Matteo Palmieri e Leonardo Datti, Pico della Mirandola, Aldo Manúcio e Gilles de Viterbo, para ressaltar apenas os mais célebres e os mais audaciosos, apesar das críticas quanto às

${ }^{4}$ Histoire de l'exégèse au XVIe siècle. Artigo de Pierre Fraenkel: Conclusion en guise d'introcuction. Genève : librairie Droz S.S., 1978.

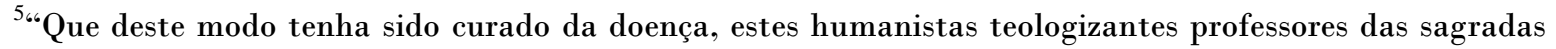
escrituras, que assim como Lutero (foram vistos terem ensinado, quanto dele terem aprendido: com o qual expoem seguramente muitas coisas que eu mesmo descreveria se pudessem ser ouvidas) seriam claramente rejeitados como os ignorantes de sua arte." (Tradução nossa.)

${ }^{6}$ Uma crítica a respeito da exegese confusa de Lutero: “Ainda que o Faraó fosse abandonado, contudo permanece o livre-arbítrio plenamente admitido por Agostinho". (Tradução nossa.) GODIN, A. apud Fisher, J. (Assertionis lutheranae confutatio, dans Opera Omnia) in Érasme, lecteur d'Origene.

NASCIMENTO, Sidnei Francisco do. Erasmo de Rotterdam no debate entre o humanismo, a escolástica e a reforma. Griot: Revista de Filosofia, Amargosa, Bahia, v.16, n.2, p.56-66, dezembro/2017. 
audácias metafísicas da teologia de Orígenes, não tinham receio das contraofensivas regidas pela faculdade de teologia de Paris. Embora seja importante ressaltar que a fascinação que esses autores mantinham pelas obras de Orígenes não era a mesma vivenciada por Erasmo e os humanistas cristãos. Envolvidos com a atmosfera promovida pela filosofia platônica, os humanistas italianos estavam muito mais voltados para uma perspectiva filosófica, o que justificaria o interesse principalmente pelo neoplatonismo cristão de Orígenes. Segundo a opinião de André Godin, em seu livro Érasme lecteur d'Origène, como gramático e pioneiro em crítica bíblica, até Lorenzo Valla ignorava completamente o alexandrino.

Erasmo se debatia com a insídia da ortodoxia propalada pelos Illustrium Ecclesiae doctorum, com o agostinismo exacerbado da Reforma e com o paganismo da Renascença. Defensor incondicional da tolerância, acabava semeando a discórdia por não se declarar sem restrições a favor de qualquer movimento. Conhecia a dialética de Boécio e sua tradução das obras de Aristóteles, mas preferia a retórica de Cícero, Horácio e Quintiliano para falar bem e conhecer o sujeito a respeito do que se trata. Curiosa situação! Erasmo exaltava a retórica clássica extraída dos exemplos da literatura pagã, mas ao mesmo tempo zombava daqueles humanistas e poetas de seu tempo, que se propunham a falar em público a respeito da morte de Cristo, quando recorriam a certas palavras, certas figuras de linguagens, certas cadências dos discursos que pronunciavam. A orientação seria de que o orador devesse em primeiro lugar se preocupar com a adaptação ou acomodação (accommodatio) do estilo ao sujeito tratado. Não se deveria falar de qualquer jeito sobre qualquer assunto, não se importando para quem. No seu colóquio Ciceronianus (1528), Erasmo escreveu que dava vontade de rir pela situação patética daqueles que se propunham a imitar a eloquência de Cícero e que se esqueciam do essencial, isto é, do sentimento e das paixões que deveriam nutrir os discursos. A exegese de Erasmo será especificamente cristã, relativizada e contaminada por seu humanismo crítico e retórico.

Antes de estudar sistematicamente as obras de Orígenes, por volta de 1475, Erasmo fora influenciado pelo contato que manteve durante algum tempo com "os irmãos da vida comum" na casa de Deventer, quando se deixou seduzir pelas qualidades literárias e a elegância de estilo de Jerônimo. O projeto erasmiano de uma edição revisada e comentada das Hieronymi Epistolae apareceu em nove volumes em 1516, mesmo ano da primeira edição do Novo Testamento. Preocupado com a pureza do texto, um bom tradutor deveria, em primeiro lugar, recorrer às fontes e ao mesmo tempo preservar o sentido do texto por meio de uma sinceridade, de integridade e pureza da fé. Essa foi a recomendação que seu amigo, professor de teologia da universidade de Louvain, representante de uma tendência moderada entre os partidários da Igreja tradicional, Martin Dorp, fez por meio de uma carta que foi escrita em 1514 e que fora considerada célebre pela longa resposta que Erasmo lhe concedeu. (ALLEN, 1517, T.II, Ep.35)

Apenas para se ter uma ideia aproximada do teor dessa correspondência e a maneira como esse conteúdo refletia a difícil relação entre a ortodoxia, os tradutores e os editores, ressalto a preocupação do amigo quanto às correções e anotações que Erasmo

NASCIMENTO, Sidnei Francisco do. Erasmo de Rotterdam no debate entre o humanismo, a escolástica e a reforma. Griot: Revista de Filosofia, Amargosa, Bahia, v.16, n.2, p.56-66, dezembro/2017. 
desenvolveu em suas correções a partir das traduções que Jerônimo fez dos manuscritos gregos. An libros Graecos credis esse Latinis emendatiores?7 A questão era a seguinte: os manuscritos gregos eram mais puros dos que os latinos? Ou os padres e concílios agiram levianamente seguindo a Vulgata, ou essa é verdadeira e pura. Sendo assim, a sugestão do amigo era que Erasmo tivesse o bom senso e corrigisse eventuais incorreções provocadas pela inabilidade ou negligência dos tradutores, incompetência dos tipógrafos ou dos copistas sonolentos, e que o fizesse sem comprometer o sentido das passagens contidas nas Sagradas Escrituras.

Erasmo não tinha dúvidas quanto ao trabalho de tradução de Jerônimo, que assim como Orígenes era devedor por seus trabalhos de exegeta, anotações, paráfrases e apologias variadas de sua teologia bíblica. O humanista reconhecia as explicações gramaticais ou filológicas da escritura desenvolvidas por Jerônimo. Erasmo o considerava como o príncipe dos teólogos em língua latina, que o inspirou em seu trabalho de tradutor e comentador do Novo Testamento.

Testamentum, quod vocant, novum omni qua licuit diligentia, quaque decuit fide recognovimus, idque primum ad graecam veritatem, ad quam ceu fontem si quid inciderit confugere, non solum illustrium theolorum exempla suadent, verum et ipsa romanorum pontificum decreta jubent. (ÉRASME, Vol.10, 1979) 8

Antes de se deixar seduzir pelas obras de Orígenes, a cultura patrística de Erasmo se limitava a Jerônimo e a Agostinho. O humanista descobria em Steyn em 1493-1494, no mosteiro de sua ordem, a doutrina cristã de Agostinho e a lia com paixão. Erasmo lera as obras de Agostinho e certamente o considerava um dos arautos da doutrina cristã. No entanto, em uma de suas citações, André Godin, em sua obra Érasme lecteur d'Origène, nos diz que o humanista era muito mais afeito ao gênio literário de Agostinho do que propriamente as suas qualidades como pensador metafísico e religioso. (GODIN, A. 1982, p.663)

As obras de Agostinho foram retomadas e estudadas pelos medievais. Isso significava que o doutor de Hipona tinha prestígio e era considerado uma autoridade que também fazia parte de um grupo seleto de autores que, por meio da ractio studiorum, adentravam as escolas medievais. Os empréstimos que Erasmo fazia da doutrina de Agostinho significava menos uma adesão total, completa, do que um recurso prudentemente tático à auctoritas para fazer frente à tirania dialética da escolástica. Agostinho já manifestava certas características da dialética, o que o distanciaria da Philosophia Christi propagada pelo humanista cristão. Embora Erasmo considerasse o segundo livro da Doutrina Cristã de Agostinho indispensável para a preparação

\footnotetext{
${ }^{7}$ Porventura, os livros gregos são confiáveis e os latinos corrigidos? (Tradução nossa.)

8 "Para os que invocam o Novo Testamento que deve merecer o cuidado de todos, em todos os lugares, é necessário confrontá-lo com fidelidade, primeiramente com a verdade grega, pois é necessário se recorrer à fonte para não serem suprimidos os exemplos que exortam os ilustres teólogos, mesmo os que julgam verdadeiros os decretos dos pontífices romanos." (Tradução nossa.)
}

NASCIMENTO, Sidnei Francisco do. Erasmo de Rotterdam no debate entre o humanismo, a escolástica e a reforma. Griot: Revista de Filosofia, Amargosa, Bahia, v.16, n.2, p.56-66, dezembro/2017. 
intelectual do futuro teólogo/exegeta como ratio verae theologiae, ${ }^{9}$ ele contrastava as obras de Jerônimo, Ambrósio, Teofilato e Crisóstomo com o estilo, o gosto das assonâncias para a dialética e por último a propensão para definir as questões de maneira franca de Agostinho.

Quod si Augustinus citra operam praeceptoris tantam eruditionem consecutus est, quid sentiendum de Origenis ingenio, quale vix unquam habuit docta Graecia, felicissimorum ingeniorum parens. Ut autem facilius, ita et felicius discuntur, quae jam inde a teneris annis percipiuntur. Origenis nulla pars aetatis periit a studiis. Beatus Augustinus usque ad annum trigesimum a religion fuit alienus, et catechumenus ac baptizatus nonnihil aetatis in profanis disciplinis contrivit. Ambrosius jam adultus a munere civili simul et ad baptismum et ad sacerdotium arreptus est. Uterque docendo discere coactus est. Origenis ingenium sufficiebat ad omnia perdiscenda.(LB. 1706, Livro VI) 10

Enquanto o doutor de Hipona privilegiava o aspecto intelectual como se a escritura fosse somente coisa de especialista, Erasmo acreditava que o evangelho deveria servir para o cidadão comum. O humanista cristão chegou a dizer que aprendia Plus me docet christianae philosophiae unica Origenis pagina quam decem Augustinill. (ALLEN. 1517, Livro III. I.)

Para compreender a controvérsia entre os humanistas cristãos e os escolásticos, seguiremos a orientação de G. Chantraine, S.J em seu artigo L'Apologia ad Latomum: deux conceptions de la théologie, onde sublinha primeiramente que há uma noção epistemológica indispensável (segundo os escolásticos) como auxiliar da teologia, e depois ressalta que (segundos os humanistas) a exegese será um auxílio indispensável para a verdadeira teologia. Já de início é importante observar que admitiremos duas concepções de teolologia: uma apriorística, e uma outra exegética, sendo esta última inseparável da interpretação literal, histórica, espiritual e alegórica que Erasmo defendia.

Mas foi em relação à discussão referente ao primeiro livro da Doutrina Cristã de Agostinho entre Jacques Masson, dito, Latomus e Erasmo que se evidenciou o debate

\footnotetext{
${ }^{9}$ Método da verdadeira teologia. (Tradução nossa.)

10

"Supõe-se que Agostinho tenha obtido com muito trabalho a erudição dos preceptores, como o talento de Orígenes para conhecer e possuir de qualquer maneira, algumas vezes com dificuldade, o felicíssimo talento dos antepassados. Estes com mais facilidade, pois foram conhecidos, desta maneira, como os mais felizes, os quais, por sua vez, já foram compreendidos e conservados com o tempo. Nenhum estudo de Orígenes perece com a idade. $\mathrm{O}$ divino Agostinho foi até os 30 anos estranho à religião, e também, até certa idade, como catecúmeno ou batizado, consumia as disciplinas profanas. Ambrósio, já adulto e simultaneamente afável para a graça, foi arrebatado para o batismo e também para o sacerdócio. Ambos foram impelidos para ensinar e aprender. Provinha do talento de Orígenes aprender bem todas as coisas." (Tradução nossa.)

11 "Ensina-me muito mais filosofia cristã em uma página de Orígenes do que em dez de Agostinho." (Tradução nossa.)
}

NASCIMENTO, Sidnei Francisco do. Erasmo de Rotterdam no debate entre o humanismo, a escolástica e a reforma. Griot: Revista de Filosofia, Amargosa, Bahia, v.16, n.2, p.56-66, dezembro/2017. 
entre teologia e exegese, isto é, entre uma concepção de teologia especulativa, aos moldes dos escolásticos, e uma outra, incentivada pelo humanista, que considerava inconcebível separar o conhecimento das coisas divinas, do conhecimento das Escrituras. Erasmo acreditava que para se conhecer as Escrituras seria necessário o conhecimento das três línguas, a saber, do grego, do latim e do hebraico. No entanto, para Latomus a teologia não tem necessidade do conhecimento da língua, visto que esta não é necessária para o conhecimento de Deus. Se, para compreendermos as Sagradas Escrituras é indispensável o conhecimento do latim, do grego e do hebraico; e se os escolásticos desprezam o conhecimento das línguas, portanto, consideram, por sua vez, que as Escrituras não são necessárias para se conhecer os mistérios de Deus. Assim, qual seria a maneira mais apropriada para se conhecer os mistérios de Deus, já que os escolásticos admitiam que não seria possível conhecê-los pelas Escrituras?

O ensino das belas letras sendo desconsiderado pelos escolásticos, resistia reiteradamente ao método pedagógico incentivado e organizado por Erasmo para ser ministrado no Colégio de Louvain. O humanista admitia que, se o desenvolvimento do ensino das línguas estivesse comprometido, a renovação da teologia viria a ser quase impossível. Para compreender a discussão entre teologia e exegese, devemos, em primeiro lugar, entender a maneira como Latomus e Erasmo tomavam partido pelo agostinismo, pelo origenismo, e qual será a relação que esses autores estabelecerão entre exegese e teologia para privilegiar ou negar a importância das línguas para compreender e interpretar os Livros Sagrados.

\footnotetext{
Para fazer passar Agostinho para o campo da escolástica, Latomus retoma o argumento do livro I, do De Doutrina que lhe permite realizar esta operação: para aquele que conhece Deus pela fé, pela esperança e pela caridade, as Escrituras, declara Agostinho, não são mais necessárias: elas terão a utilidade de um veículo que conduz a este conhecimento. Sobretudo, conclui Latomus, o conhecimento das línguas não seria necessário, visto que ela serve para interpretar as Escrituras. (G. CHANTRAINE, S.J. 1969, p.57)
}

Erasmo, de maneira sempre moderada para não acirrar ainda mais os ânimos com novas polêmicas, responde ao seu interlocutor com muito cuidado e sutilidade, objetivando propor uma justificativa aos seus detratores como se não estivesse tomando partido da discussão. Nessas situações de embates lembramos da imagem que os retratistas fizeram do humanista, aparentemente indiferente às polêmicas. Propositalmente ou não, Erasmo não dará muita importância a dialética à filosofia que a Doutrina Cristã de Agostinho lhe reservara, pois, veremos, que para ele, existem dois agostinismos: um escolástico e outro envolvido com a antiga teologia, que Erasmo irá demominar como a verae theologiae. A eclesiologia de Latomus e sua epistemologia racional e dedutiva conceberá a teologia como o conhecimento das coisas divinas (rerum divinarum cognitio), ou mesmo como a ciência das coisas santas (sacrarum rerum scientia); seja como for, o que o escolástico pretendia era ratificar a tese de Agostinho, que haveria uma separação entre as letras e o conhecimento de Deus. Para isso sua eclesiologia terá de admitir que conhece Deus por meio de um intelecto que está

NASCIMENTO, Sidnei Francisco do. Erasmo de Rotterdam no debate entre o humanismo, a escolástica e a reforma. Griot: Revista de Filosofia, Amargosa, Bahia, v.16, n.2, p.56-66, dezembro/2017. 
acima do indivíduo humano, pois "a alma intelectiva, quando intelige em ato, participa dos inteligíveis, porque recebe por participação as espécies inteligíveis". Embora não aceitasse o inatismo platônico completamente, para Agostinho, o pensamento conhece a verdade iluminada por Deus, o pai da luz inteligível:

Esta metáfora da iluminação já estava presente na filosofia platônica, mais precisamente no mito da caverna, em que o sol representava a verdade para os prisioneiros acorrentados em seu interior, vivendo num mundo de sombras e de enganos. As ideias são para Agostinho protótipos e pensamentos divinos, segundo os quais tudo é formado. Essa iluminação divina supõe o intelecto incriado, luz inteligível superior, exterior ao nosso intelecto, que lhe dá sentido e significação. Embora o doutor de Hipona considere a existência de um Deus criador inexistente na filosofia de Platão, no entanto, ambos rejeitavam a participação dos sentidos para a construção do conhecimento intelectual. (NASCIMENTO.S. 2013, p. 220)

Essa separação entre teologia e exegese operada pela síntese que Agostinho desenvolveu do inatismo platônico por meio da teoria da iluminação, também se verifica entre as palavras e as coisas familiar à lógica dos nominalistas. Enquanto a metafísica de Agostinho admitirá a luz sobrenatural com relação ao Evangelho, a teoria da abstração presente na epistemologia dos nominalistas dirá que os conceitos são anteriores às palavras, pois não são resultados de uma cultura, ou história em particular. Tudo é claramente e distintamente concebido pela inteligência humana como inerente às naturezas individualmente determinadas, como, por exemplo, o som, o nome que representam um pensamento, um conceito, que não é ele próprio a imagem de qualquer natureza universal, pois nada existe no interior das coisas a título de universal. Assim, os conceitos, produzidos pela luz natural ou inteligência, percebem a natureza das coisas. Na compreensão dos conceitualistas, as palavras não pertencem a nenhuma língua em particular, pois dependem essencialmente dos conceitos, que, por um processo de indução abstrativa, significam naturalmente. $O$ conceitualismo presente da discussão que Latomus desenvolve contrapondo-se à exegese erasmiana, se corresponde em parte à tese aristotélica que faz do universal um conceito. Portanto, nem o Evangelho possui uma relação orgânica com a tradição, nem as palavras são histórica e culturalmente definidas.

Tanto a teoria da iluminação e a luz sobrenatural, quanto a teoria da abstração e a luz natural (ambas teorias universais), cada uma ao seu modo, não conceberiam a exegese história/literal e mística/alegórica. "A visibilidade do Evangelho seria a lei mental de Cristo, comparado àquela dos sacramentos." (G. CHANTRAINE, S.J. 1969, p.63) Se a luz sobrenatural contém a verdade Evangélica, a luz natural contém a verdade das coisas nomeadas pelas palavras. Latomus entende, dessa maneira, a afirmação de Agostinho de uma maneira absoluta, que não deixa lugar ao progresso histórico e espiritual.

Mas, por outro lado, no interior da ortodoxia, para manter a tradição, em detrimento de sua teologia especulativa, Latomus daria espaço às pretensões de Lutero no momento em que descontextualizaria a narrativa dos apóstolos. Com sua

NASCIMENTO, Sidnei Francisco do. Erasmo de Rotterdam no debate entre o humanismo, a escolástica e a reforma. Griot: Revista de Filosofia, Amargosa, Bahia, v.16, n.2, p.56-66, dezembro/2017. 
epistemologia racional e dedutiva, que separa a teologia da exegese, ele rejeitaria ao mesmo tempo, a exegese de Jerônimo ao privilegiar o Agostinho dialético, e a exegese de Orígenes, ao desarticular história, alegoria e teologia. Mas, ao separar a teologia da exegese, não estaria aí a fresta onde se construirá a subjetividade e autonomia da retórica protestante? Latomus, ao rejeitar as transformações sugeridas por Erasmo, concedendo-lhe a pecha de um autor herético, faria soprar os ventos da reforma protestante. Paradoxalmente o humanista cristão, com suas "modernidades", se esforçava para reformar a Igreja, fazendo que se mantivesse cada vez mais viva a tradição depurada de todo pragmatismo que Orígenes também combateu em Alexandria.

Erasmo reprovará os teólogos de cair em argúcias dialéticas, de preferir a disputa e os silogismos à piedade da prece. A teologia escolástica, quando dogmatiza, é considerada como uma excrescência doutrinal, inútil, pretensiosa e maléfica, tudo como as cerimônias que recobriram os preceitos simples e leves de Jesus. Se a palavra toma a forma de uma parábola ou de um discurso é necessário tomar consciência dessas modalidades expressivas, que são como a carne da mensagem. "É necessário coincidir o máximo com a realidade complexa do Livro Santo para que o senhor se manifeste a nós na sua verdade e se renda autenticamente presente em nossos espíritos e em nossa vida." (J. ETIENNE. 1969, p. 08) Seria possível encontrar o ponto de chegada à exegese de Orígenes a partir da oposição que se estabeleceu entre Erasmo e a escolástica ao final da Idade Média.

Cientes da relação direta entre a teologia de Paulo, as alegorias de Orígenes, as traduções de Jerônimo, a retórica clássica e a proposta exegética e teológica de Erasmo, caminharemos, a seguir, à procura metodológica de um princípio de coerência bíblica, de uma teoria hermenêutica, de uma prática exegética na contramão do método de exegese tradicional incentivado pelas escolas medievais.

NASCIMENTO, Sidnei Francisco do. Erasmo de Rotterdam no debate entre o humanismo, a escolástica e a reforma. Griot: Revista de Filosofia, Amargosa, Bahia, v.16, n.2, p.56-66, dezembro/2017. 


\section{Abreviaturas}

ALLEN - Opus epistolarum D. Erasmi, Vol. II: 1514-1517. (Ed. P. S. Allen). Oxford University Press, 2012 (on line)

LB - Erasmi opera omnia. Leyde, 1703-1706.Leyde: J. Clericus, 1703-1706.

\section{Referências biliográficas}

ÉRASME. Les Silènes d'Alcibiade. Tradução, introdução e notas por Jean-Claude Margolin. Paris: Les belles lettres, 1998.

. Les Préfaces au Novum Testamentum (1516). Introdução e Comentários por Yves Delègue. Genève: Labor et Fides. 1990.

. La Correspondence d'Érasme. Aos cuidados de d'Alois Gerlo e Paul Foriers.

Bruxelles: European Academic Press, Vol. 12, nº 10, 1979.

GODIN, André. Érasme lecteur D'Origène. Genève: Librairie Droz 1982.

NASCIMENTO, Sidnei. F. Sobre o conhecimento intelectual humano. Suma de Teologia,

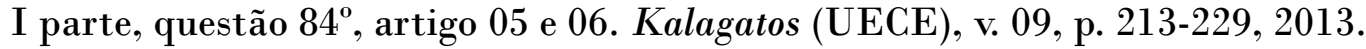

FRAENKEL, Pierre. Conclusion en guise d'introduction. In: Histoire de l'exégèse au XVIe siècle. Genève: librairie Droz S.S., 1978.

G. CHANTRAINE, S.J. L'Apologia ad Latomum: deux conceptions de la théologie. In:__ Scrinium Erasmianum. Vol. II. Leiden: E.J. Brill, 1969.

ÉTIENNE.J. La Médiation des Écritures selon Érasme. In:__ Scrinium Erasmianum. Vol II. Leiden: E.J. Brill, 1969.

Autor(a) para correspondência: Sidnei Francisco do Nascimento, Universidade Federal do Maranhão, Av. dos Portugueses, 1966, Vila Bacanga, CEP 65080-805, São Luís - MA, Brasil.

NASCIMENTO, Sidnei Francisco do. Erasmo de Rotterdam no debate entre o humanismo, a escolástica e a reforma. Griot: Revista de Filosofia, Amargosa, Bahia, v.16, n.2, p.56-66, dezembro/2017. 